\author{
Andrzej Zborowski \\ https://orcid.org/0000-0002-6268-3594 \\ andrzej.zborowski@uj.edu.pl \\ Halina Pawlak \\ halina.pawlak@gmail.com \\ Jadwiga Gałka \\ https:/ / orcid.org/0000-0002-6728-8497 \\ email: jkb.misiak@gmail.com \\ Uniwersytet Jagielloński \\ Wydział Geografii i Geologii \\ Instytut Geografii i Gospodarki Przestrzennej
}

\title{
RELACJE SPOŁECZNE MIĘDZY MIESZKAŃCAMI WSI I LUDNOŚCIĄ NAPŁYWOWA Z MIASTA W STREFIE PODMIEJSKIEJ KRAKOWA - PRZESTRZEŃ KONFLIKTU CZY WSPÓŁPRACY?
}

\begin{abstract}
Abstrakt: Badania strefy podmiejskiej w Polsce mają długą tradycję i prowadzone były w wielu ośrodkach naukowych. Równie poważny dorobek powstał $\mathrm{w}$ zakresie badań społecznych tej strefy. Studia te jednak są prawie wyłącznie prowadzone z pozycji mieszkańca miasta zasiedlającego strefę podmiejską, motywów jego migracji i postrzegania stosunków społecznych w nowym miejscu zamieszkania. W polskiej literaturze przedmiotu brak jest natomiast badań na temat postaw mieszkańców wsi podmiejskich wobec ludności napływającej z miasta centralnego. Tę lukę w literaturze przedmiotu starali się wypełnić autorzy niniejszego opracowania. Poddali bowiem badaniu pod tym kątem mieszkańców trzech gmin podmiejskich, położonych w strefie oddziaływań Krakowa.
\end{abstract}

Słowa kluczowe: konflikt społeczny, postawy mieszkańców, strefa podmiejska, Kraków.

\section{SOCIAL RELATIONS BETWEEN LOCAL RESIDENTS OF VILLAGES AND MIGRANTS FROM THE CITY IN THE SUBURBAN ZONE OF KRAKOW - A SPACE OF CONFLICT OR COOPERATION?}

Abstract: Studies on suburban zone in Poland have a long tradition and being realized in several research centres. Significant achievements concerns also the field of social research of this zone. But social studies on this zone are almost all realized from the new resident's point of view who has come from the city and settled in the suburban zone; his/her motives of migration and perception of social relations in the new place of residence. Therefore, in the Polish literature on the suburban zone, lack investigation on the attitudes of local residents of suburban villages towards those who have come from the central city. The authors' study aims to stop a gap. The above attitudes have been examined among the residents of three suburban municipalities located in the Krakow zone of influence.

Keywords: social conflict, attitudes of residents, suburban zone, Krakow.

\section{WSTĘP}

Strefy podmiejskie zarówno miast dużych, jak i średnich a nawet małych, stały się w Polsce w okresie przejścia kraju do gospodarki rynkowej areną fundamentalnych przemian funkcjonalnych, społeczno-demograficznych i urbanistyczno-morfologicznych. Tereny te zostały ze szczególną siłą poddane oddziaływaniu obszarów centralnych miast. Uwidoczniło się to na wielu terenach wiejskich położonych pod miastem, wymykających się spod kontroli planistycznej procesów chaotycznej urbanizacji (urban sprawl) i ich zabudowywaniu na modłę miejską. Procesy te znane wcześniej $\mathrm{z}$ miast Zachodu w Polsce ujawnily się w latach 90. XX w., $\mathrm{z}$ początku $\mathrm{w}$ miastach dużych, by następnie objąć miasta średnie i mniejsze (Lisowski, Grochowski, 2008; Runge, 2011; Zborowski, Raźniak, 2013). Polską suburbanizację od zachodniej odróżniał jednak przede wszystkim brak polityki przestrzennej 
w miastach, który ujawnił się zwłaszcza w strefach podmiejskich $w$ okresie omawianej ekspansji miejskiej na tereny wiejskie. Brak tej polityki szedł w parze z koniunkturalnym ruchem inwestycyjnym pozbawionym kontroli administracyjnej $\mathrm{w}$ wyniku anulowania w Polsce w 1994 r. ważności miejscowych planów zagospodarowania przestrzennego. Spowodowany tym chaos funkcjonalno-przestrzenny został pogłębiony za sprawą niemal równocześnie postępującego (obok procesów suburbanizacji rezydencjonalnej) wypełniania przestrzeni wiejskich nowymi terenami przemysłowymi oraz usługowymi (suburbanizacja usługowo-przemysłowa). Kolejnym wyróżnikiem polskiej wersji suburbanizacji było duże zróżnicowanie typów zabudowy. Obok domów jednorodzinnych wolnostojących pojawiła się zabudowa szeregowa oraz wielorodzinna, przypominająca dzielnice miejskie i często będąca wręcz przestrzenną kontynuacją zabudowy miejskiej na bezpośrednio $\mathrm{z}$ tym miastem graniczących terenach wiejskich, które nazywamy terenami adurbanizacji (Turzyński, 2017).

Typ zabudowy, przede wszystkim cena gruntów budowlanych i ich odległość od ośrodka centralnego, a także dostępność do miejsca pracy i szkół determinują skład społeczny osiedli podmiejskich. Wymienione czynniki decydują o motywach migracji z miasta do wsi podmiejskich. Prowadzi to do ukonstytuowania się w strefie podmiejskiej dwóch układów społeczno-osadniczych, na które składają się: 1) strefa podmiejska bliższa (miejska) i dalsza (wiejska) oraz 2) strefa dojazdów do pracy (Zborowski, 2005).

Strefa podmiejska jest tu traktowana szeroko jako obszar objęty oddziaływaniem miasta centralnego głównie przez dojazdy mieszkańców strefy podmiejskiej do pracy, szkół i usług; wyróżnia się też napływem na pobyt stały ludności z ośrodka centralnego oraz rozwojem działalności usługowej i produkcyjnej, lokowanej w niej w ramach procesów decentralizacji (strefa podmiejska bliższa).

Strefa dojazdów do pracy natomiast charakteryzuje się rozwojem procesów peryurbanizacyjnych, określanych również mianem suburbanizacji rozszerzonej (extended suburbanisation). Z racji dominujących w niej procesów strefa dojazdów do pracy w literaturze zachodniej najczęściej nazywana jest strefą peryurbanizacji (Europa Zachodnia), względnie eksurbanizacji (Stany Zjednoczone).

Strefy suburbanizacji i peryurbanizacji różnią się funkcjami, typem zabudowy (morfologią), powiązaniami społecznymi z ośrodkiem centralnym, dostępnością do tego ośrodka oraz przekrojem spo- łecznym (Zborowski, Gałka, Śliwińska, 2016). Tym, co je zasadniczo wyróżnia jest obecność funkcji rolniczej, silniej rozwiniętej w strefie peryurbanizacji, a niewystępującej w strefie suburbanizacji. Istotne różnice dotyczą też skali koncentracji osadnictwa, które $\mathrm{w}$ bliżej położonej strefie suburbanizacji jest silnie skoncentrowane, a w bardziej odległej strefie peryurbanizcji mocno rozproszone. Strefy te są także odmienne ze względu na status społeczny zamieszkującej je ludności. W strefie suburbiów jest stosunkowo duży udział tzw. klasy średniej i rodzin pełnych $\mathrm{z}$ dziećmi $\mathrm{w}$ wieku szkolnym. W strefie peryurbanizacji zaś struktura społeczna jest bardzo zróżnicowana - obejmuje rolników i producentów rolnych, przedstawicieli klasy średniej i wyższej. Są wśród nich rodziny w fazie "pustego gniazda" i młode rodziny "na dorobku”, których nie było stać na zakup mieszkania $\mathrm{w}$ mieście centralnym.

Te struktury decydują też o charakterze więzi społecznych i relacji ludności napływowej z mieszkańcami wsi podmiejskich. Odmienne style życia osób przybyłych z miasta $\mathrm{w}$ konfrontacji ze społecznością lokalną wsi prowadzą często do braku zrozumienia miejscowych przez "obcych" i na odwrót. Również zmiana (często bardzo gwałtowna) funkcji rolniczych, pełnionych dotychczas przez podmiejskie wsie, na rezydencjonalne i usługowe, a w jej następstwie spore wymieszanie funkcjonalne, mogą prowadzić do dużych napięć w takiej społeczności. Mogą pojawiać się sytuacje konfliktowe, które nie od razu zwykle ujawniają się, lecz utajone trwają latami.

\section{UWAGI}

\section{TERMINOLOGICZNO-TEORETYCZNE}

Konflikt społeczny (z łac. conflictus) oznacza w ścisłym tłumaczeniu: zderzenie, walkę. Współcześnie jest uważany za zjawisko powszechnie występujące i nieuniknione, które niekiedy może prowadzić do destrukcji i występowania nieprawidłowości w życiu społecznym. $Z$ drugiej strony uznaje się, że warunkuje on osiąganie pewnych stanów równowagi społecznej (Sielezin, 2010). Według Simmla (1975) konflikt przyczynia się do wzrostu poziomu tożsamości grupowej i wewnętrznej solidarności grupowej, natomiast zdaniem Cooley'a (Jermakowicz, 2014) prowadzi do rozwoju twórczości i innowacyjności. Inny klasyk teorii konfliktu społecznego Coser $(1975$, s. 199) uważa, że „Konflikt w grupie 
społecznej [...] może przyczynić się do osiągnięcia jedności lub do przywrócenia jedności i spójności zagrożonej przez wrogie i antagonistyczne uczucia między członkami". Coser zwraca jednocześnie uwagę na to, że nie każdy konflikt może wywołać pozytywne skutki.

Zagadnienie konfliktu społecznego jest przedmiotem zainteresowania wielu dyscyplin naukowych, takich jak: socjologia, psychologia, politologia, nauki o środowisku przyrodniczym, gospodarka przestrzenna, urbanistyka oraz geografia społeczna. Oznacza to istnienie różnych podejść do zagadnień terminologicznych, rozwiązań analitycznych i metodologicznych. Stwarzają one pole do wielu interpretacji tego procesu, a także powodują sporą dywergencję terminologiczną. Dotyczy to przede wszystkim definicji tego procesu, które wypływają z różnych sposobów rozumienia konfliktu społecznego.

Jak zauważa Mucha (2014), w naukach społecznych występują co najmniej trzy powiązane empirycznie, jednak analitycznie nieidentyczne pojmowania tego terminu. Pierwsze $\mathrm{z}$ nich, opisywane jako strukturalne, za konflikt uważa istnienie obiektywnie występujących sprzeczności interesów w zakresie dostępu do określonych i pożądanych dóbr przez dane grupy społeczne funkcjonujące $\mathrm{w}$ określonym systemie społecznym. $\mathrm{W}$ tym podejściu istotny jest fakt, że grupy te nie zawsze uświadamiaja sobie sprzeczności interesów, natomiast sprzeczności te można potwierdzić metodami naukowymi. Należy zatem uznać, że pierwsze podejście stwarza podstawy do badań konfliktów społecznych in statu nascendi, czyli można tu mówić o konflikcie społecznym potencjalnym. Drugie podejście do konfliktu społecznego według Muchy (2014) dotyczy behawioralnej lub interakcyjnej koncepcji rozumienia konfliktu społecznego. W tym przypadku konflikt jest pojmowany w kategoriach „walki” różnych grup interesu, która ma prowadzić do realizacji interesów jednej ze stron konfliktu kosztem pozostałych. Trzecie pojęcie konfliktu, zgodnie z opinią tej autorki, jest formułowane na gruncie analiz psychospołecznych. W tym podejściu konflikt jest postrzegany jako stan wrogości, a jego podłoże często stanowią emocje, które $\mathrm{w}$ trakcie trwania konfliktu mogą eskalować.

Inne rozumienie tego terminu jest oparte na treści konfliktu, którego strukturę można prześledzić na tzw. kole Moore'a (1996). Zgodnie z tym autorem można wyróżnić konflikty: relacji, danych, wartości, strukturalny i interesów (rys. 1). Konflikt relacji uzewnętrznia się $\mathrm{w}$ negatywnym stosunku ludzi wobec siebie, a towarzyszą mu silne emocje i stereotypowe postrzeganie. Konflikt danych występuje wówczas, gdy społeczeństwo nie ma dobrych informacji lub w ogóle ich brakuje, względnie są one interpretowane błędnie. Konflikt wartości wynika z różnic ideologicznych, religijnych, czy też odniesień do tradycji, różnego rozumienia dobra i zła. Z kolei konflikt strukturalny jest wywołany nierównym dostępem do zasobów, o które konkurują ludzie, może też wynikać $\mathrm{z}$ różnych ról, jakie odgrywają, nierównego rozkładu sił pośród grup społecznych. Wyróżniamy też konflikt interesów, który dotyczy trzech ich rodzajów: interesów materialnych, proceduralnych i psychologicznych, postrzeganych w kontekście aspiracji i motywacji działań człowieka i grup społecznych.

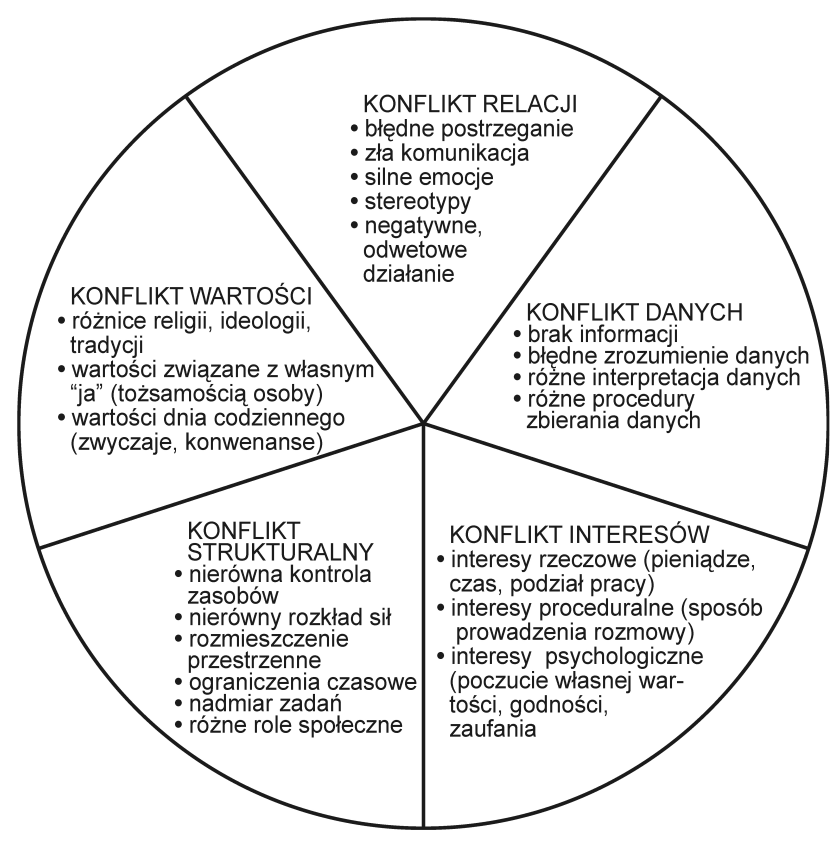

Rys. 1. Struktura konfliktu - koło Moore'a Źródło: Moore (1996, s. 60-61)

W zakresie zainteresowań geografów leżą przede wszystkim konflikty, których zasadniczym komponentem jest przestrzeń, a ich zakres pojęciowy jest zależny od aspektu leżącego u podstaw konfliktu. W tym przypadku możemy mówić o konfliktach środowiskowych i ekologicznych, lokalizacyjnych, przestrzenno-funkcjonalnych, lokalnych i miejskich (urban conflict) oraz konfliktach przestrzennych (Borys, 1989; Czarnecki, 2011; Dmochowska-Dudek, 2011; Dudek-Mańkowska, Lackowska-Madurowicz, 2012; Dutkowski, 1996; Głogowska, Szendera, Chmielewski, 2013; Grocholska, 1980, 1986; Majer, 2000; Śleszyński, Solon, 2010). Konflikty te są rozmaicie definiowane i systematyzowane. Konflikty 
przestrzenne dzieli się na konflikty przestrzeni i konflikty w przestrzeni (inaczej: funkcjonalne).

Konflikty przestrzeni występują wówczas, gdy ten sam obszar może pełnić dwie funkcje, które wykluczają się nawzajem (np. funkcja aprowizacyjna i rezydencjonalna, względnie przemysłowa). Konflikty funkcjonalne dotyczą lokalizacji pewnych funkcji w zasięgu niekorzystnego oddziaływania innej (np. nowa strefa mieszkaniowa $\mathrm{w}$ zasięgu oddziaływania zakładów przemysłowych). Interesującym podziałem konfliktów w przestrzeni jest podział Dutkowskiego (1995), który wyróżnił trzy rodzaje sytuacji konfliktowych: 1) między użytkownikami dóbr środowiskowych a służbami ochrony środowiska występującymi w interesie ogólnym, 2) pomiędzy użytkownikami dóbr środowiskowych, oraz 3) między zwolennikami różnych sposobów użytkowania dóbr środowiskowych. Z kolei Przewoźniak (2008) klasyfikuje konflikty w zagospodarowaniu przestrzeni według istoty sporu, wyróżniając konflikty o: 1) zasoby przyrody związane z dostępnością do zasobów antropogenicznych i naturalnych (w tym terenu), 2) jakość przestrzeni - konflikty ekologiczne, 3) funkcje przestrzeni. Ostatnie dotyczą sposobów korzystania z terenu i jest to najczęściej spotykany typ konfliktów.

Ponieważ każdy konflikt ma naturę społeczną, również konflikty, których istotą jest spór o przestrzeń, można zaliczyć do jednej z kategorii konfliktów społecznych. Takie stanowisko zajmuje także Markowski (1999). Zauważył on, że konflikt o podłożu przestrzennym różni się od klasycznego konfliktu społecznego tym, że $\mathrm{u}$ jego podstaw leży spór o sposób użytkowania ziemi. Należy tu dodać, że każdy konflikt przestrzenny jest związany ze sposobem użytkowania ziemi lub wzrostem intensywności tego użytkowania przez człowieka; przedmiotem sporu jest tu użytkowanie przestrzeni, a podmiotem - jednostka lub grupa społeczna.

W przypadku strefy podmiejskiej, która jest szczególnym przedmiotem zainteresowania autorów niniejszego artykułu, występują liczne konflikty, obserwowane i potencjalne, które - za Mantey (2016) - można sprowadzić do pewnej typologii konfliktów przestrzennych. Obejmuje ona konflikty związane z procesami suburbanizacji, terenami cennymi przyrodniczo, procesami urbanizacji na obszarach podlegających ochronie i szczególnie cennych przyrodniczo, procesami urbanizacji na terenach presji turystycznej, $\mathrm{z}$ obszarami rozpraszania zabudowy i wzrostu intensywności użytkowania ziemi. Pawlak (2014) przedstawiła typologię konfliktów na terenach wiejskich - według istoty konfliktu, jego uczestników i przedmiotu konfliktu. Konflikty te $\mathrm{w}$ dużej mierze występują $\mathrm{w}$ strefie podmiejskiej i dotyczą głównie własności gruntów, użytkowania ziemi i przemian funkcjonalnych oraz rodzą się na tle społeczno-kulturowym.

\section{CEL, IDEA I MIEJSCE BADAŃ}

Jako cel niniejszego artykułu ustanowiono zbadanie postaw mieszkańców podkrakowskich wsi wobec ludności napływowej z miasta centralnego. Zakłada się, że postawy te mogą być naznaczone i obarczone funkcjonującymi w społeczności lokalnej stereotypami, które w kontaktach "miejscowych" z „obcymi" moga prowadzić do sytuacji konfliktowych, związanych z życiem codziennym zasiedziałych i napływowych mieszkańców wsi podmiejskich. Badanie konfliktów społecznych na drodze stawiania respondentom bezpośrednich pytań dotyczących istniejących konfliktów należy do złożonych zagadnień. Mieszkańcy podmiejskich wsi niezbyt chętnie chcą informować osoby z zewnątrz o istniejących problemach społecznych. Dlatego też wydaje się dobrym zabiegiem badanie postaw jednej społeczności wobec drugiej, co pozwala na poznanie opinii na temat występujących ewentualnych (potencjalnych) konfliktów we wsiach podmiejskich.

Szczególnie słabo na gruncie polskim jest rozpoznana tematyka postaw mieszkańców wsi wobec napływających osób z miasta, o czym świadczy małe zainteresowanie tą tematyką $w$ literaturze omawiającej konflikty na tle społecznym, rozgrywające się przede wszystkim na obszarach podmiejskich. Należy dodać, że procesy suburbanizacji i peryurbanizacji są badane najczęściej z pozycji mieszkańców miast, jak np.: badanie motywów przenoszenia się mieszkańców miasta na wieś, ich składu społecznego, poziomu życia (Kurek, Wójtowicz, Gałka, 2014). Brak natomiast szerszej wiedzy na temat opinii i postaw rdzennych mieszkańców wsi wobec ludności napływającej z miasta centralnego. Dlatego w niniejszym badaniu autorzy chcą uzyskać odpowiedzi na wiele kwestii nurtujących społeczność wiejską, takie jak: postawy i obawy mieszkańców wsi wobec osób napływających z miasta, gotowość do sprzedaży ziemi "obcym", stopień integracji przybyszy z miasta $\mathrm{z}$ nowym miejscem zamieszkania w ocenie mieszkańców wsi.

Podmiotem badania byli mieszkańcy trzech podmiejskich gmin położonych $\mathrm{w}$ strefie peryferyjnej obszaru metropolitalnego Krakowa: Mogilan, Gdowa i Igołomi-Wawrzeńczyc (rys. 2). 


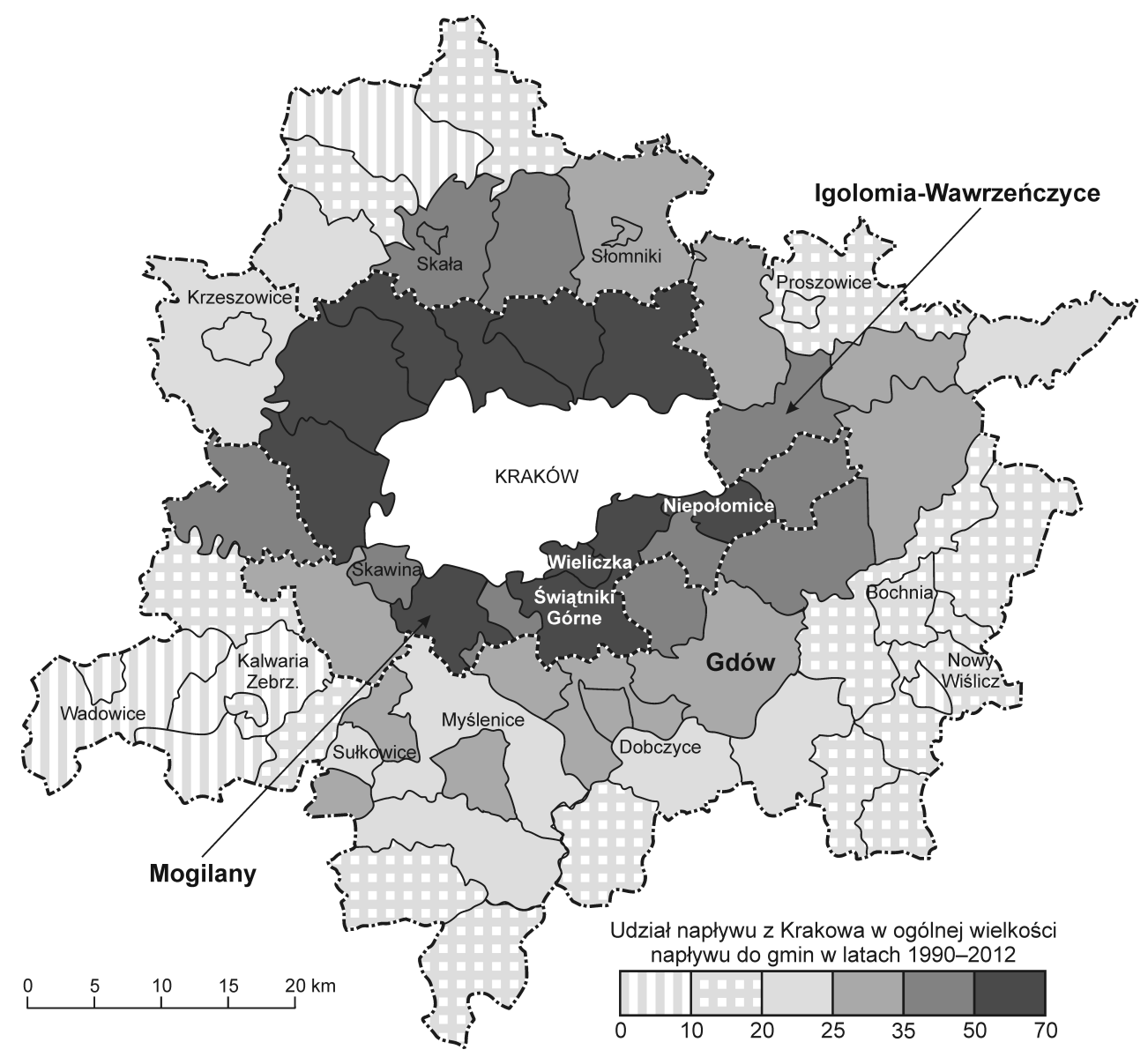

Rys. 2. Zmiany udziału napływu z Krakowa w ogólnym napływie migracyjnym do gmin strefy podmiejskiej i dojazdów w latach 1990-2012

Źródło: Kurek, Wójtowicz, Gałka (2014)

Badany teren dzieli się na dwie części. Pierwszą $\mathrm{z}$ nich jest strefa podmiejska wytyczona na podstawie istniejących powiązań funkcjonalnych i cech strukturalnych, a drugą zasięg dojazdów do pracy do Krakowa, wyznaczony w oparciu o cechy funkcjonalne (Zborowski, Trafas, 2003; Zborowski, Chaberko, Kretowicz, 2011). Gmina Mogilany została zaliczona do strefy podmiejskiej, natomiast gminy Gdów i Igołomia-Wawrzeńczyce do strefy dojazdów do pracy. $W$ pierwszej $z$ wymienionych gmin dominują procesy suburbanizacji, w pozostałych dwóch przewagę mają procesy peryurbanizacji, na co wskazuje m.in. udział napływu mieszkańców Krakowa do gmin strefy podmiejskiej i strefy dojazdów do pracy w latach 1990-2012 (Kurek, Wójtowicz, Gałka, 2014). W strefie podmiejskiej udział ten kształtuje się na poziomie około $60 \%$ ogólnego napływu do tej strefy, natomiast w strefie dojazdów jest on znacząco niższy i nie przekracza $25 \%$.

Wybrane do badań trzy gminy różnią się zarówno charakterem procesów demograficznych, jak i strukturą gospodarczą (tab. 1). Najwyższy poziom urbanizacji przejawia gmina Mogilany, położona niespełna $10 \mathrm{~km}$ od centrum Krakowa, o dużej gęstości zaludnienia, przekraczającej ponad 6-krotnie średnią gęstość zaludnienia dla wsi w Polsce (313 osób $/ \mathrm{km}^{2}$ ). O stopniu zawansowania procesów suburbanizacyjno-peryurbanizacyjnych wiele mówi także wskaźnik udziału ludności napływowej z Krakowa w ogólnej liczbie migrantów do danej gminy w latach 1990-2012. Aż 59\% z ogółu przybyłych do gminy Mogilany pochodziło z Krakowa, podczas gdy dużo niższe wartości tego wskaźnika odnotowano w pozostałych dwóch gminach. Gmina Mogilany wyróżniała się też bardzo wysokim udziałem migrantów z innych miast Polski (ok. 25\%). Łącznie z napływem z Krakowa stanowili oni $85,4 \%$ spośród ogółu przybyszy. Podobnie wysokim udziałem migrantów miejskich (24\%) mogła wykazać się też gmina Gdów, która wyróżniała się dużą imigracją ze wsi położonych poza tą gminą. Ten typ krzyżujących się napływów występuje najczęściej na terenach wiejskich objętych procesami peryurbanizacyjnymi. 
Tab. 1. Charakterystyka wybranych gmin Krakowskiego Obszaru Metropolitalnego na tle województwa i Polski

\begin{tabular}{|c|c|c|c|c|c|}
\hline Wyszczególnienie & Mogilany & Gdów & $\begin{array}{c}\text { Igołomia- } \\
\text { Wawrzeń- } \\
\text { czyce }\end{array}$ & $\begin{array}{c}\text { Woj. mało- } \\
\text { polskie }\end{array}$ & Polska \\
\hline \multicolumn{6}{|c|}{ A. Sytuacja demograficzna } \\
\hline Liczba ludności w gminie w 2016 r. & 13655 & 17865 & 7721 & 3382260 & 38432992 \\
\hline Liczba ludności na 1 km² w 2016 r. & 313 & 164 & 123 & 223 & 123 \\
\hline Dynamika zmian liczby ludności (2002 r. = 100) & 131,8 & 112,6 & 100,9 & 104,5 & 100,6 \\
\hline Dynamika zmian liczby ludności (1995 r. = 100) & 144,5 & 117,9 & 101,8 & 106 & 99,5 \\
\hline Średni przyrost naturalny w latach 1995-2016 na 1000 mieszkańców & 3,6 & 3,7 & 0,1 & 1,7 & 0,2 \\
\hline $\begin{array}{l}\text { Współczynnik salda migracji; średnia z lat 1995-2016 na } 1000 \text { miesz- } \\
\text { kańców }\end{array}$ & 11,7 & 3,7 & 0,5 & 0,8 & $-0,3$ \\
\hline $\begin{array}{l}\text { Udział ludności napływowej z miasta w ogólnym napływie w latach } \\
\text { 1995-2016 }\end{array}$ & 85,4 & 58,2 & 64,4 & 57,4 & 60,2 \\
\hline $\begin{array}{l}\text { Udział ludności napływowej z Krakowa w ogólnej liczbie napływów } \\
\text { w latach 1990-2012 }\end{array}$ & 59 & 34,3 & 44,7 & - & - \\
\hline \multicolumn{6}{|c|}{ B. Zagadnienia gospodarcze } \\
\hline Dochody (zł) własne gminy na 1 mieszkańca w 2016 r. & 2115 & 1278 & 1258 & 2130 & 2368 \\
\hline Podmioty wpisane do rejestru REGON na 10 tys. ludności w 2016 r. & 1331 & 888 & 730 & 1097 & 1103 \\
\hline $\begin{array}{l}\text { Udział zarejestrowanych bezrobotnych w liczbie ludności w wieku } \\
\text { produkcyjnym w } 2016 \mathrm{r} \text {. }\end{array}$ & 3,7 & 4,3 & 1,8 & 4,6 & 5,6 \\
\hline Liczba złożonych wniosków o dopłaty obszarowe w ARiMR w 2012 r. & 218 & 1451 & 1251 & 121234 & 1359084 \\
\hline $\begin{array}{l}\text { Powierzchnia użytków rolnych (ha) wnioskowana do dopłat bezpo- } \\
\text { średnich w } 2012 \text { r. }\end{array}$ & 617 & 5561 & 4215 & - & - \\
\hline $\begin{array}{l}\text { Udział powierzchni wnioskowanej o dopłaty bezpośrednie do użyt- } \\
\text { ków rolnych ogółem w } 2012 \text { r. }\end{array}$ & 19 & 65 & 80 & - & - \\
\hline
\end{tabular}

Źródło: opracowanie własne na podstawie danych GUS, ARiMR oraz Kurek, Wójtowicz, Gałka (2014).

Struktura gospodarcza omawianych gmin jest również bardzo zróżnicowana (część B tab. 1). Świadczy o tym poziom dochodów własnych gmin na 1 mieszkańca. W 2016 r. jedynie w gminie Gdów sięgały one średniej dla województwa małopolskiego, a ewidentnie niższe zanotowano $\mathrm{w}$ pozostałych dwu gminach, co wskazuje na istotny udział funkcji rolniczych $\mathrm{w}$ gospodarce tych gmin. Potwierdza tę konstatację wysoki wskaźnik przedsiębiorczości w Mogilanach, a względnie niski w Gdowie i Igołomi-Wawrzeńczycach. O znacznym udziale rolnictwa $\mathrm{w}$ gospodarce dwóch uprzednio wymienionych gmin świadczy także duża liczba złożonych wniosków o dopłaty obszarowe w Agencja Restrukturyzacji i Modernizacji Rolnictwa (ARiMR) oraz odsetek powierzchni wnioskowanej o dopłaty bezpośrednie w użytkach rolnych ogółem - szczególnie wysoki w Igołomi-Wawrzeńczyce. Warto dodać, że gmina ta posiada duży areał gruntów pod foliami i szklarniami, co pozwala jej pełnić typowo aprowizacyjne funkcje dla Krakowa, a także częściowo dla konurbacji katowickiej.

\section{4. ŹRÓDŁA POTENCJALNYCH KONFLIKTÓW SPOŁECZNYCH}

Opierając się na zaprezentowanym uprzednio podziale konfliktów występujących na terenach wiejskich $\mathrm{w}$ analizie źródeł potencjalnych konfliktów społecznych odniesiono się do konfliktów społeczno-kulturalnych i konfliktów wynikających z użytkowania ziemi oraz przemian funkcjonalnych. Szczególną uwagę zwrócono na możliwość wystąpienia na badanym obszarze konfliktów na tle kulturowym. Potencjalne konflikty tego typu mocno mogą zaznaczyć się głównie w strefach oddziaływania wielkiego miasta. Są one jednak niezmiernie trudne do zbadania, bowiem mieszkańcy, nawet bardzo podzieleni w kwestiach społeczno-kulturowych, rzadko ujawniaja podczas wywiadów czy ankietowania występowanie tego typu konfliktów. Dlatego w trakcie przeprowadzania badań potencjalne konflikty były oceniane $\mathrm{w}$ drodze pytań zadawanych "nie wprost”, a zatem sondujących ogólne nastroje, postawy wobec sąsiadów czy systemy wartości. 
Do ważnych społecznie kwestii należy m.in. poznanie opinii na temat wzajemnych postaw mieszkańców wobec siebie. Postawy te badano w kontekście istniejących w społecznościach lokalnych układów, które wpływają na ocenę obaw przejawianych wobec osób napływowych z miasta przez rdzennych mieszkańców. Umożliwiło to poznanie stosunków społecznych w grupach sąsiedzkich analizowanych gmin w ujęciu kontradyktoryjnym "swoi -obcy".

Pytanie o obawy przed osobami napływającymi $\mathrm{z}$ miasta postawiono respondentom będącym rdzennymi mieszkańcami trzech badanych gmin. Najwięcej zgłaszających tego typu obawy ujawniło się w gminie Gdów (rys. 3) - było to niemal 30\% ogółu ankietowanych. Jednocześnie $\mathrm{w}$ tej gminie bardzo małą grupę stanowili respondenci zdecydowanie nieobawiający się napływu mieszkańców z miasta. $\mathrm{Z}$ kolei najmniej niechętni wobec nowych mieszkańców okazali się badani z gminy Igołomia-Wawrzeńczyce, gdyż ponad połowa z nich nie zgłosiła żadnych obaw przed przybyszami. Pośrednie stanowisko przyjęli zaś mieszkańcy gminy Mogilany. Takie proporcje odpowiedzi znajdują wytłumaczenie $\mathrm{w}$ funkcjach tych gmin, ale też należy przypisać duże znaczenie natężeniu zjawiska migracji o charakterze suburbanizacyjnym.

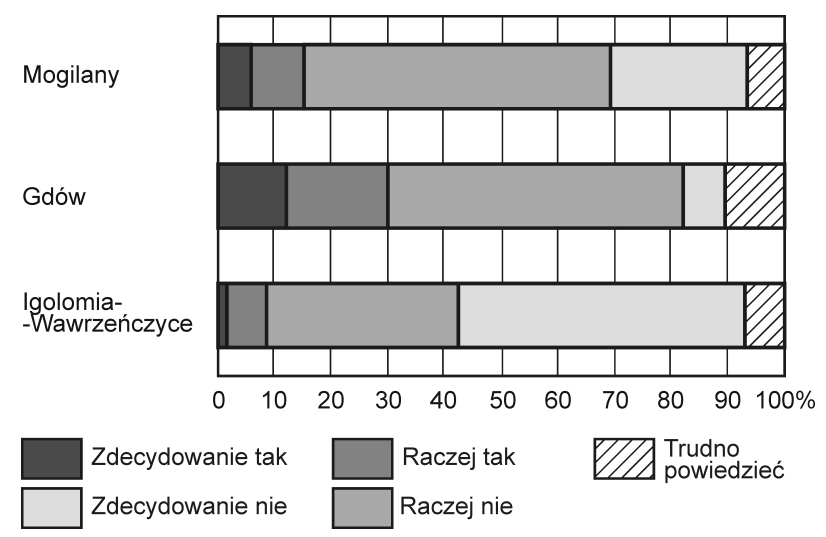

Rys. 3. Odpowiedzi respondentów na pytanie: czy obawia się Pani/Pan osób napływowych z miasta? Źródło: opracowanie własne na podstawie Pawlak (2017)

Dotychczasowe badania wykazują, że funkcja rolnicza wyróżnia się znacznym skonfliktowaniem z funkcją rezydencjonalną, która zwiększa swoje znaczenie na skutek dużego napływu ludności z miasta. Gmina Gdów cechuje się bardzo dobrze rozwiniętym rolnictwem towarowym i drobnotowarowym. W ostatnich kilkunastu latach postępował $w$ niej silny proces imigracyjny $z$ miast, głównie $\mathrm{z}$ Krakowa. Zatem stwierdzone wcześniej oba- wy mieszkańców tej gminy są uzasadnione i szczególnie silne wśród pracujących $\mathrm{w}$ rolnictwie. Zdecydowane obawy przed przybyszami wyrażało $23 \%$ ankietowanych posiadających gospodarstwa o powierzchni powyżej 10 ha, które na w tej części Polski należą do grupy dużych jednostek produkcyjnych.

Odmienną postawę wobec mieszkańców pochodzących z miasta prezentowali respondenci w gminie Igołomia-Wawrzeńczyce. Gminę tę, pełniącą funkcje wybitnie rolnicze ( $w$ przeciwieństwie do gminy Gdów), cechuje bardzo mały napływ mieszkańców z miast, w tym z Krakowa. Jest to gmina o wysokotowarowym rolnictwie wyspecjalizowanym w dostarczaniu na rynek Krakowa i konurbacji katowickiej warzyw, uprawianych przede wszystkim w tunelach foliowych. Jej położenie na zachód, w niedużej odległości od kombinatu stalowego Arcelor Mittal Steel, nie zachęca krakowian do wybierania tej gminy na miejsce stałego osiedlenia się. A zatem miejscowa ludność, znając preferencje migracyjne krakowian, nie obawia się dużych fal napływu, co odzwierciedla się w strukturze ich odpowiedzi.

Potencjalny konflikt społeczny można zidentyfikować także w kontekście samooceny społeczności lokalnej w podziale: „,napływowi - lepsi”, , "miejscowi - gorsi". Ten rodzaj podziału społecznego mocniej niż układ "swoi-obcy" odzwierciedla faktyczny stosunek ludności miejscowej do napływowej z miasta. W każdej z badanych gmin twierdzenia, że nowi mieszkańcy uważają się za osoby „lepsze" były częściej artykułowane niż obawy przed ich napływem z miasta. Struktura przestrzenna odpowiedzi była natomiast podobna, tzn. najwięcej było pejoratywnych odczuć, wskazujących, że "miejscowi - gorsi" od "napływowych - lepszych”, w gminie Gdów, a najmniej takich postaw odnotowano w gminie Igołomia-Wawrzeńczyce (rys. 4).

Takie zróżnicowanie struktury wypowiedzi respondentów $\mathrm{w}$ badanych gminach należy tłumaczyć zakresem podejmowanych kontaktów z nowymi mieszkańcami pochodzącymi z miasta. Prawdopodobieństwo wystąpienia tych kontaktów, na skutek dużego napływu mieszkańców z Krakowa, jest znacznie większe w gminach Gdów i Mogilany niż w gminie Igołomia-Wawrzeńczyce. Struktura odpowiedzi na omawiane pytanie wskazuje dobitnie, że poczucie przez miejscową ludność bycia "gorszym" jest odpowiednim probierzem potencjalnego konfliktu na poziomie psychospołecznym, który - jak wynika z badania - ujawnia się mocniej w przypadku większego napływu ludności z miast. 
Znamienny jest fakt, że omawiane odczucia są mocno uzależnione od dochodów respondentów przypadających na osobę $\mathrm{w}$ gospodarstwie domowym. W grupie gospodarstw o najniższych dochodach odczucia podziału na "lepszych" i "gorszych" są najsilniejsze. W gospodarstwach domowych o najwyższych dochodach podział ten jest mniej istotny. To zróżnicowanie wynika (jak można sądzić) z zakorzenionego na wsi stereotypu opisującego ludność napływową z miast jako bogatą, posiadającą wysoki status społeczny, a takie przekonanie szczególnie mocno jest zakorzenione $\mathrm{w}$ grupach słabszych materialnie.

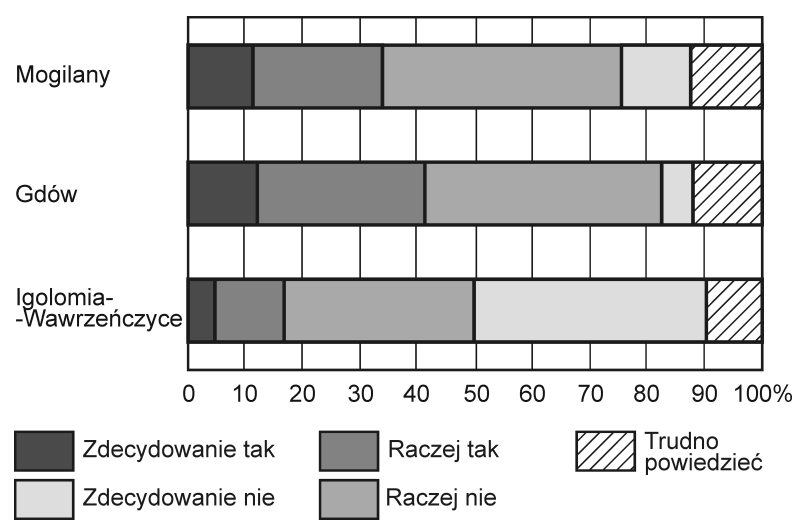

Rys. 4. Odpowiedzi respondentów na pytanie: czy spotkał(a) się Pani/Pan z odczuciem, że nowi mieszkańcy uważają się za osoby „lepsze"?

Źródło: opracowanie własne na podstawie Pawlak (2017)

Potencjalnym konfliktom może zapobiec integracja i włączenie nowych mieszkańców do lokalnej społeczności. Zatem istotne jest pytanie, czy zdaniem respondentów osoby napływowe integrują się $\mathrm{z}$ rdzenną ludnością. Uzyskane odpowiedzi na to pytanie znów wskazują na istniejące $\mathrm{w}$ tym zakresie duże różnice między badanymi gminami (rys. 5).

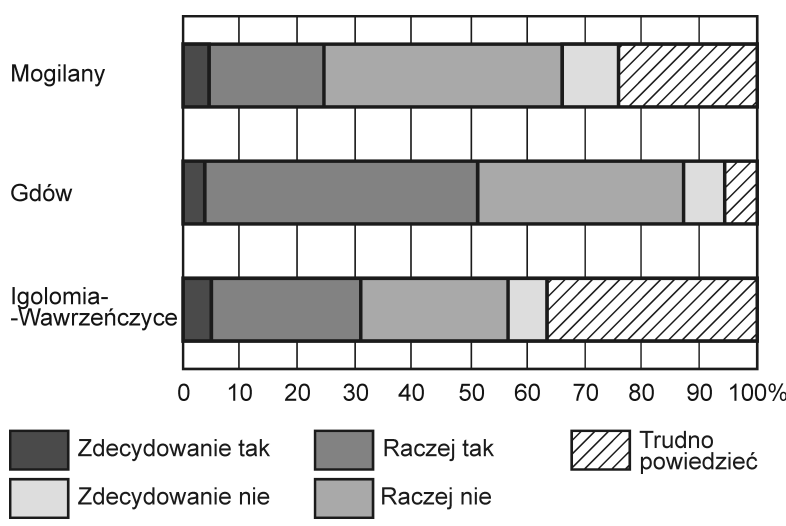

Rys. 5. Odpowiedzi respondentów na pytanie: czy nowi mieszkańcy chcą się integrować i utożsamiać z tą miejscowością? Źródło: opracowanie własne na podstawie Pawlak (2017)
O zachodzących procesach integracyjnych najszerzej wypowiadali się mieszkańcy gminy Gdów, gdzie ponad połowa ankietowanych uznała, że napływowi sąsiedzi z miasta przejawiają chęć do integracji. Znacznie gorzej doświadczenia integracyjne oceniali respondenci w gminie Mogilany, spośród których tylko $24 \%$ potwierdziło występowanie zjawiska integracji $\mathrm{w}$ ich miejscowości. Tak znaczne rozbieżności w postawach wobec integracji można tłumaczyć wieloma czynnikami. Do najważniejszych należy zaliczyć trzy z nich, mianowicie: typ układu przestrzennego nowego osadnictwa, czas zamieszkiwania respondenta $\mathrm{w}$ danej miejscowości oraz odległość od Krakowa miejscowości, do której przybył migrant.

W gminie Gdów nowe budownictwo mieszkaniowe jest rozproszone, co oznacza, że powstało wewnątrz starego układu osadniczego. Takie rozmieszczenie nowych zasobów mieszkaniowych wymusza niejako potrzebę codziennych kontaktów mieszkańców z miasta z ludnością miejscową, a to prowadzi do szybszej i głębszej integracji obu tych grup. Inny typ nowego osadnictwa występuje w gminie Mogilany, gdzie pojawiają się liczniej większe i mniejsze skupienia osadnictwa realizowanego $\mathrm{w}$ systemie deweloperskim, $\mathrm{w}$ postaci m.in. grodzonych osiedli. Z racji takiej przestrzennej separacji nowi mieszkańcy tylko sporadycznie doświadczają kontaktów z miejscową ludnością.

O kontaktach i integracji decyduje też odległość miejscowości zamieszkania nowych mieszkańców od Krakowa. Im dalej z danej miejscowości do miasta centralnego, tym częściej podstawowe potrzeby nowych mieszkańców są zaspokajane w miejscu osiedlenia, co sprzyja wzmocnieniu kontaktów i pośrednio prowadzi do integracji.

Długość zamieszkania respondentów w danej miejscowości jest kolejnym czynnikiem pobudzającym lub też hamującym procesy integracyjne. Najmniej doświadczeń integracyjnych mają przybysze krócej mieszkający w danej miejscowości. Więcej kontaktów służących integracji dostrzegają respondenci, którzy rezydują już co najmniej 10 lat w danej miejscowości. Oznacza to, że aby móc ocenić zjawisko integracji, trzeba najpierw samemu być dobrze zintegrowanym z miejscową społecznością. Krócej zamieszkujące ankietowane osoby podchodzą do procesu integracji z większym dystansem, sami bowiem dobrze pamiętają własne problemy $\mathrm{z}$ integracją $\mathrm{w}$ nowym środowisku zamieszkania.

Analizowane powyżej postawy mieszkańców gmin podmiejskich wobec napływowej ludności 
z miasta wskazują, że powszechne, aczkolwiek zróżnicowane co do stopnia postrzegania, jest podzielanie obaw dotyczących różnych wymiarów dezintegracji społeczności wsi. Zróżnicowanie to jest podyktowane m.in. natężeniem napływu ludności z miasta i, co się z tym wiąże, sporej dyspersji przestrzennej popytu na działki budowlane w strefie podmiejskiej. Pojawia się zatem pytanie: czy mieszkańcy wsi podlegających procesom suburbanizacji zauważają $\mathrm{w}$ swoim otoczeniu wzrost zainteresowania zakupem działek budowlanych? Dostrzeżenie bowiem przez nich chęci ich zakupu wskazuje na wzrost atrakcyjności danego obszaru jako osiedleńczego. Może być także zwiastunem przyszłych procesów "rozlewania się miasta”, prowadzących do nasilenia się potencjalnych konfliktów społecznych. Pytani o to mieszkańcy wsi dostrzegali wzrost popytu na działki budowlane we wszystkich analizowanych gminach. Zjawisko to było najczęściej wymieniane przez respondentów z gminy Mogilany, co nie jest zaskoczeniem, bowiem $\mathrm{w}$ tej gminie procesy suburbanizacyjne przybrały bardzo duże rozmiary (rys. 6).

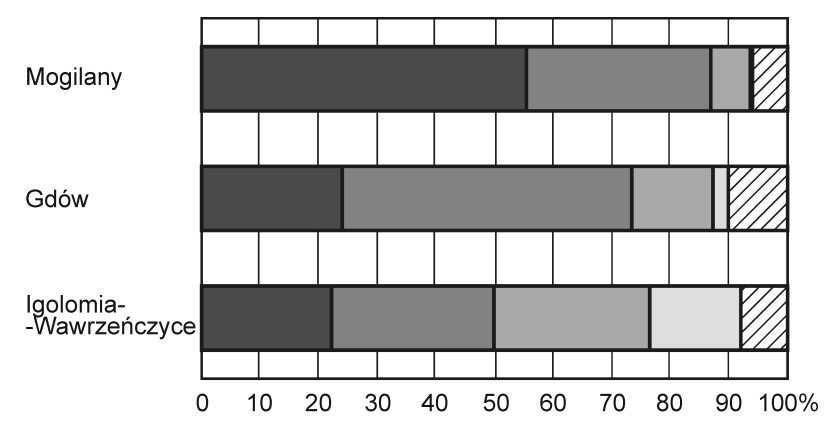

Zdecydowanie tak Zdecydowanie nie

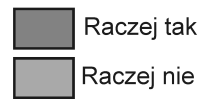

$\nabla$ powiedzieć

Rys. 6. Odpowiedzi respondentów na pytanie: czy zauważył Pan/Pani wzrost zainteresowania działkami budowlanymi w Pana/Pani miejscowości?

Źródło: opracowanie własne na podstawie Pawlak (2017)

W gminie tej aż $87 \%$ ankietowanych osób dostrzegło wzrost zainteresowania zakupem działek budowlanych, ale zjawisko to zauważyła także większość respondentów w Gdowie (72\%). Mniej takich wypowiedzi odnotowano natomiast wśród ankietowanych $\mathrm{z}$ gminy Igołomia-Wawrzeńczyce. Trzeba jednak dodać, że również tam połowa respondentów stwierdziła rosnące zainteresowanie działkami budowlanymi. Wobec uzyskanych wyników można zatem stwierdzić, że mieszkańcy podmiejskich wsi powszechnie odnotowują zjawisko wzmożonego zainteresowania zakupem dzia- łek budowlanych w miejscu ich zamieszkania. Świadczy to bowiem o potencjalnym dużym popycie na tereny budowlane pod miastem. W związku z tym pojawia się kolejne pytanie: czy mieszkańcy wsi są zdecydowani sprzedać swoje grunty pod działki budowlane mieszkańcom pochodzącym $\mathrm{z}$ miasta? Pytanie to jest istotne $\mathrm{w}$ kontekście badanego zagadnienia, bowiem na polskiej wsi nadal istnieje bardzo silne przywiązanie do ziemi, często nadal nazywanej „ojcowizną". Ziemia była żywicielką pokoleń mieszkańców wsi i stanowiła zazwyczaj jedyne źródło utrzymania.

Od wielu lat mieszkańcy miejscowości wiejskich, zwłaszcza młodsi, podejmują jednak pracę w mieście, co wiąże się ze zjawiskiem urbanizacji ekonomicznej wsi. W strefach podmiejskich dużych miast proces ten notowany był $\mathrm{z}$ dużym nasileniem już od lat 60. ubiegłego wieku. Niemniej jednak podejście do własności ziemi i jej posiadania na wsi, nawet zurbanizowanej, nie ulega szybkim przemianom. W południowej Polsce nadal członkowie społeczności wiejskiej niechętnie rozstają się z własnym (zazwyczaj niedużym) gruntem rolnym. W świetle powyższych uwag może zastanawiać stosunkowo duży udział respondentów z gminy Gdów, którzy gotowi byli na sprzedaż działki budowlanej osobie pochodzącej z miasta. Zadeklarowało to aż $3 / 4 \mathrm{z}$ nich (w pełni zdecydowanych i raczej zdecydowanych) (rys. 7). Nieco mniejszy był udział ankietowanych wyrażających chęć sprzedaży ziemi w gminie Mogilany, natomiast zupełnie na to zdecydowanych (odpowiedź „zdecydowanie tak”) było aż 20\%. Zastanawiający jest jednak fakt, że w gminie Igołomia-Wawrzeńczyce, najbardziej rolniczej spośród badanych trzech gmin, było aż 75\% respondentów mówiących o chęci sprzedaży gruntów budowlanych, natomiast aż ponad połowa $\mathrm{z}$ nich wyraziła zdecydowanie na sprzedaż działki. Zatem czynnik ekonomiczny - pozyskanie dodatkowych pieniędzy (poza pracą) - był mocnym konkurentem obaw co do napływu mieszkańców pochodzących $\mathrm{z}$ miasta i związanych z nim potencjalnych konfliktów społecznych. Tak masowo wyrażana chęć sprzedaży działki budowlanej może też być związana $\mathrm{z}$ odchodzeniem, szczególnie młodszego pokolenia, od tradycyjnego przywiązania do ziemi i łączenia swojej przyszłości wyłącznie $\mathrm{z}$ pracą $\mathrm{w}$ mieście lub też na wsi, ale poza rolnictwem. Może też występować tu specyficzne rozłączne traktowanie tych dwóch kwestii, odpowiadające $w$ pewnym sensie syndromowi NIMBY, a zatem - „wiem, że napływ dużej liczby mieszkańców z miasta wywołuje liczne konflikty na wsi, ale gdy ja sprzedam kawałek mo- 
jego gruntu komuś z miasta, to nic złego się nie stanie".

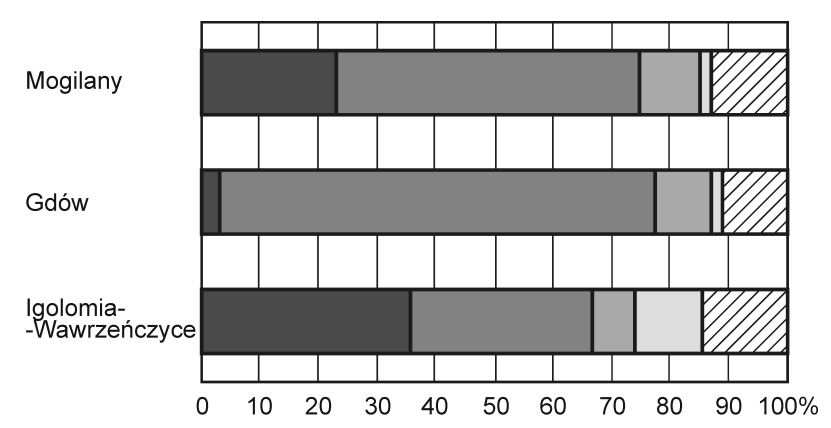

$\begin{array}{lll}\square & \text { Zdecydowanie tak } & \square \text { Raczej tak } \\ \square \text { Zdecydowanie nie } & \square \text { Raczej nie }\end{array}$

Rys. 7. Odpowiedzi respondentów na pytanie: czy sprzedałaby

Pani/Pan działkę budowlaną osobie pochodzącej z miasta?

Źródło: opracowanie własne na podstawie Pawlak (2017)

Ten tok rozumowania mogą potwierdzać odpowiedzi na pytanie o obawy mieszkańców wsi o wyczerpanie się w przyszłości wolnych terenów pod zabudowę mieszkaniową. Jedynie respondenci z gminy Mogilany dostrzegali ten problem, niespełna $30 \%$ z nich zauważyło, że w przyszłości może zabraknąć terenów budowlanych w miejscu ich zamieszkania (rys. 8).

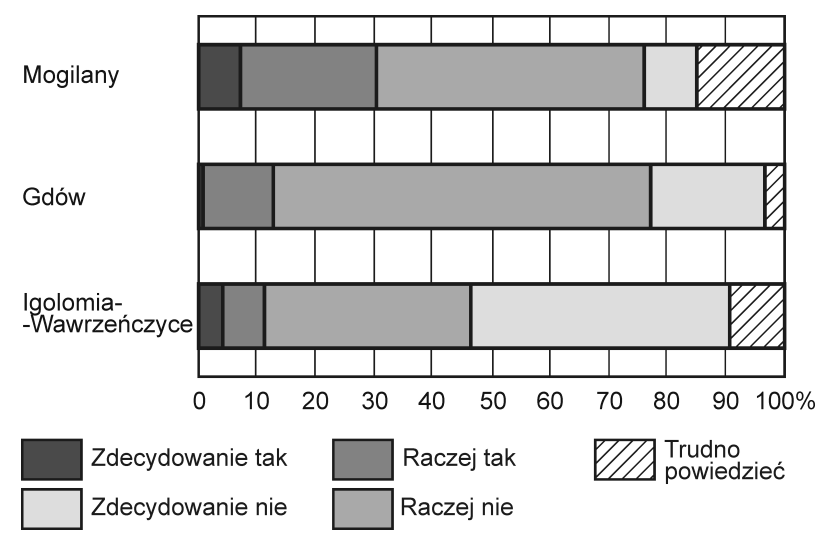

Rys. 8. Odpowiedzi respondentów na pytanie: czy obawia się Pani/Pan, że w przyszłości zabraknie terenów pod zabudowę mieszkaniową w tej miejscowości?

Źródło: opracowanie własne na podstawie Pawlak (2017)

W niewielkim stopniu natomiast zwracano uwagę na to zjawisko w pozostałych dwóch gminach. Na taki tok myślenia ma także wpływ specyficzne podejście do własności gruntów w Polsce. Każdy grunt prywatny $\mathrm{w}$ potocznej opinii pozostaje do wyłącznego zarządzania przez jego właściciela. Oznacza to, iż w rozumieniu właścicieli gruntu można nim dowolnie dysponować i przeznaczać na cele, które uznaje on za stosowne. W związku z tym wielu właścicieli gruntów rolnych domaga się tzw. odrolnienia gruntów i przeznaczenia ich na cele budowlane. Dlatego m.in. w planach zagospodarowania przestrzennego większości gmin tereny budowlane są zaplanowane $\mathrm{z}$ dużym nadmiarem, bez wyraźnej korelacji z przewidywanymi procesami przyrostu liczby ludności w danej gminie.

Znaczny problem stwarza też $\mathrm{w}$ badanych gminach duże rozproszenie nowego budownictwa mieszkaniowego. Zadano zatem respondentom pytanie o to, czy napływ nowych mieszkańców przyczynia się ich zdaniem do rozpraszania zabudowy w miejscowościach, które zamieszkują. Jak wynika $\mathrm{z}$ odpowiedzi, problem ten jest zauważany przez ankietowanych mieszkańców (rys. 9).

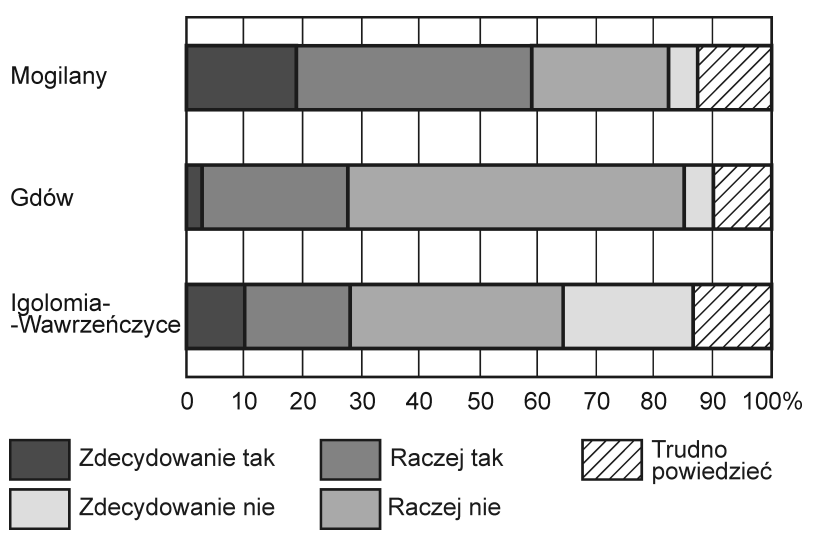

Rys. 9. Odpowiedzi respondentów na pytanie: czy napływ ludności powoduje rozproszenie zabudowy w tej miejscowości?

Źródło: opracowanie własne na podstawie Pawlak (2017)

Szczególnie mocno podkreślali to zjawisko respondenci w gminie Mogilany, którzy powszechnie spotykają się z napływem ludności z miasta i nową zabudową mieszkaniową. Około $60 \%$ z nich potwierdzilo istnienie procesu rozpraszania budownictwa mieszkaniowego, w pozostałych dwóch gminach zgodzilo się z tym twierdzeniem tylko po około $30 \%$ ankietowanych. Stosunkowo niski odsetek badanych, zwracających uwagę na omawiany proces w gminie Gdów, może być skutkiem historycznie ukształtowanej tam specyfiki budowy domów (Kiełczewska-Zaleska, 1972) i wynikającego $\mathrm{z}$ niej znacznego rozproszenia osadnictwa $\mathrm{w}$ tej gminie. Zatem sam proces rozpraszania może być traktowany przez część tamtejszych respondentów jako typowy dla zabudowy mieszkaniowej i powszechnie występujący $\mathrm{w}$ gminie, a więc niebudzący negatywnych skojarzeń w zakresie kreowania ładu przestrzennego miejscowości. 
Zaprezentowana powyżej analiza wskazuje na istotny co do skali przestrzennej i natężenia proces sukcesji funkcjonalnej, która prowadzi do wyłączania gruntów rolnych z produkcji rolniczej. Działalność rolnicza jest wypierana i zastępowana różnymi formami działalności pozarolniczej zarówno mieszkaniowej, jak i usługowej. Wcześniej wspomniano, że szczególnie dwie $\mathrm{z}$ badanych gmin (Mogilany i Gdów) mają nadal rozwinięte funkcje rolnicze, ważne dla utrzymania ich mieszkańców i gospodarki lokalnej. Powstaje więc pytanie: czy społeczność ta dostrzega proces wypierania funkcji rolniczej przez działalność pozarolniczą? Rozkład udzielonych odpowiedzi wskazuje na dość powszechne dostrzeganie tego procesu, które jest najmocniej zaakcentowane $\mathrm{w}$ wypowiedziach mieszkańców gmin Mogilany i Gdów, a w znacznie mniejszym - osób z gminy Igołomia-Wawrzeńczyce (rys. 10).

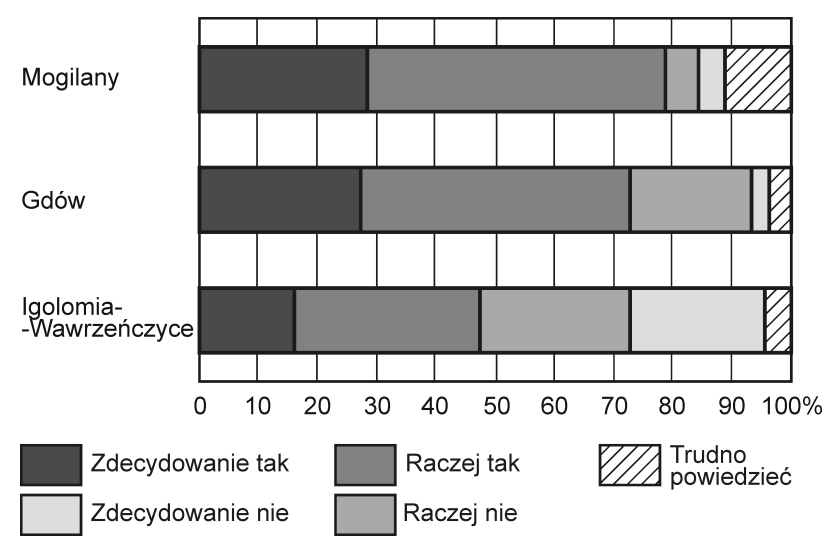

Rys. 10. Odpowiedzi respondentów na pytanie: czy według Pani/Pana następuje wypieranie produkcji rolniczej przez działalność pozarolniczą?

Źródło: opracowanie własne na podstawie Pawlak (2017)

Oznacza to, że w gminach Mogilany i Gdów może dochodzić do różnego typu konfliktów na tle prowadzenia działalności rolniczej. Stopień dostrzegania przez miejscową ludność procesu wypierania działalności rolniczej należy wiązać z licznymi czynnikami, z których dwa wydają się najistotniejsze. Pierwszym jest poziom rozwoju funkcji rolniczej, a drugim - natężenie przemian funkcjonalnych powiązane z długością okresu ich występowania. Drugi czynnik można uznać za dominujący, na co wskazuje bardzo wysoki odsetek respondentów przekonanych do wypierania funkcji rolniczej przez działalność pozarolniczą z terenów o największych przemianach funkcjonalnych związanych $\mathrm{z}$ dużym napływem ludności z miasta - czyli w gminach Mogilany i Gdów.

\section{PODSUMOWANIE}

Przeprowadzone badania wśród społeczności trzech gmin strefy podmiejskiej Krakowa ujawniły potrzeby szerokiego ujmowania pojęcia konfliktu społecznego, który może zrodzić się między ludnością miejscową i napływową z miasta. Szerokie odniesienie nawiązuje $\mathrm{w}$ dużej mierze do definicji i rozumienia tego pojęcia przez Dahrendorfa (2012). Konflikt społeczny opisany w niniejszej pracy może być rozpatrywany co najmniej na dwóch poziomach: strukturalnym i psychospołecznym. Pierwszy z nich możemy też utożsamiać z konfliktem potencjalnym. Strony potencjalnego konfliktu społecznego nie zawsze uświadamiają sobie możliwość jego wystąpienia, a jego identyfikacja zależy od odpowiednio przeprowadzonych badań społecznych, wskazujących na obiektywnie istniejące sprzeczności interesów.

W niniejszym artykule naświetlono potencjalne konflikty o charakterze społeczno-kulturowym. Sprowadzono je do badania postaw w układzie "swoi-obcy" na tle postrzegania i wzajemnych odniesień w kontekście "napływowi - lepsi”, „miejscowi - gorsi", a także obaw związanych z dezintegracją społeczności lokalnej.

W wyniku przeprowadzonego badania można też mówić o poziomie psychospołecznym takich konfliktów, co może skutkować stanami napięcia oraz niechęci (a także czasami postawy wrogości) manifestowanej przez strony konfliktu, a ujawniające się szczególnie w konfliktach na tle zmian użytkowania ziemi i konfliktach funkcjonalnych. Takie konflikty mogą być utożsamiane $\mathrm{z}$ obawami respondentów przed wypieraniem produkcji rolniczej przez działalność pozarolniczą, rozpraszaniem zabudowy, a nawet z możliwością zanikania wolnych terenów pod zabudowę.

Warto w tym miejscu odnieść wyniki referowanych tu badań do struktury konfliktu ze względu na jego treść, przedstawionej na kole Moore'a (1996). Wśród wyróżnionych przez tego badacza pięciu potencjalnych źródeł konfliktu w niniejszym badaniu możemy wyróżnić aż cztery z nich. Istnieje tu bowiem konflikt wartości, odnoszący się do podtrzymywania czy zaniku tradycji oraz podzielania zwyczajów dnia codziennego (zwyczaje i ich kultywowanie). Dostrzegamy także konflikt strukturalny, dotyczący przede wszystkim konfliktów przestrzennych, a związany $\mathrm{z}$ nierówną możliwością kontroli zasobów, o które konkurują strony; może on również wynikać z ograniczoności tych zasobów. 
Ujawniono też obawy o brak zasobów pod zabudowę $\mathrm{w}$ wyniku nadmiernej imigracji do gmin. Kolejnym rodzajem konfliktu w kole Moore'a (1996), który pojawia się na analizowanym terenie, jest konflikt relacji wyrażający się wzajemnymi negatywnymi odniesieniami jego stron, stereotypami zakorzenionymi wśród ludności miejscowej i napływowej („,napływowi - lepsi”, "miejscowi - gor$\left.\mathrm{si}^{\prime \prime}\right)$, a także brakiem komunikacji między tymi grupami. Wśród mieszkańców strefy podmiejskiej spotyka się również następny z wymienionych przez przywołanego autora - konflikt interesów, związany z ograniczeniem możliwości spełnienia potrzeb, np. psychologicznych, takich jak: poczucie własnej wartości i godności, czy też szacunku (w tym badaniu postawy typu „lepsi - gorsi").

Identyfikacji konfliktu społecznego w trakcie naszych badań dokonano w dwóch wymiarach - społeczno-kulturowym i na tle użytkowania ziemi (konflikt funkcjonalny) - co pozwoliło wskazać dwie trajektorie przemian konfliktów i ich możliwych ścieżek rozwoju. Trajektorie te, odnoszące się do wzrostu napięć i potencjalnego kreowania konfliktu, ewentualnie do zmniejszania wzajemnych animozji i wygaszania potencjalnego zarzewia konfliktu społecznego, zależą od kilku czynników, w tym np. od stopnia natężenia kontaktów interpersonalnych potencjalnych stron konfliktu, tj. ludności napływowej i miejscowej. Wiąże się to $\mathrm{z}$ kolei $\mathrm{z}$ rozmiarem napływu osób z miasta oraz czasem trwania procesów suburbanizacyjnych na danym obszarze podmiejskim. Obie trajektorie możemy ująć w trzy fazy czasowe.

Pierwsza z trajektorii opisuje przebieg konfliktu społecznego w jego wymiarze społeczno-kulturowym. W pierwszej fazie napięcia konflikty między rdzennymi mieszkańcami a ludnością napływową są nieliczne (jak np. w gminie Igołomia-Wawrzeńczyce) z racji stosunkowo słabych kontaktów obu grup. Wraz ze wzrostem napływu ludności z miasta pojawiają się pierwsze problemy, które mogą urastać do rangi konfliktów społecznych. Mogą się one zaznaczyć szczególnie mocno na obszarze suburbanizacji „kieszonkowej”, kiedy dochodzi do przenikania się nowego budownictwa ludności miejskiej i starej zabudowy wiejskiej (gmina Gdów). Dłuższe trwanie imigracji i pewne zasiedzenie ludności napływowej $\mathrm{z}$ miasta służy wzajemnemu poznaniu, co może prowadzić do osłabienia emocji i uprzedzeń oraz znacząco ograniczyć możliwość pojawienia się tego rodzaju konfliktu (gmina Mogilany).
Inny przebieg natężenia zjawiska ma trajektoria konfliktu społecznego na tle funkcjonalnym. Podobnie jak w poprzednim przykładzie, początkowa sprzedaż działek i (co się z nią łączy) wykupywanie ziemi, a także obawy o przyszły niedostatek terenów pod zabudowę $\mathrm{w}$ gminie oraz kolizje interesów na tle wypierania produkcji rolnej przez inną działalność są znikome. Zatem także możliwość wystąpienia konfliktu na tym tle jest niewielka (gmina Igołomia-Wawrzeńczyce). Dopiero wraz z przestrzenną ekspansją nowych funkcji (w tym mieszkaniowej), wzmożoną sprzedażą działek oraz wzrostem stopnia rozproszenia zabudowy pojawiają się liczne konflikty na tle przemian użytkowania ziemi - czyli konfliktów w wymiarze funkcjonalnym (gmina Gdów). Przybierają one na sile wraz z postępowaniem suburbanizacji w strefie podmiejskiej (gmina Mogilany). Może zatem wystąpić niezgodność między trajektorią konfliktu społecznego w wymiarze kulturowym i wymiarze funkcjonalnym. W pierwszej fazie obie trajektorie charakteryzują się małym natężeniem konfliktu, w drugiej fazie konflikt na tle kulturowym szybko się rozwija i wzmacnia, podczas gdy natężenie potencjalnego konfliktu na tle funkcjonalnym jest jeszcze przeciętne - rośnie ono dopiero w fazie trzeciej, wówczas gdy nowe funkcje zdominują stare. W tym samym czasie $\mathrm{w}$ fazie trzeciej notujemy natomiast zmniejszanie się możliwości wystąpienia konfliktu spolecznego na tle kulturowym.

\section{BIBLIOGRAFIA}

Borys, T. (1989). Konflikt ekologiczny w Kotlinie Jeleniogórskiej - geneza, przebieg i perspektywy rozwiązania. Rocznik Jeleniogórski, 25/26, s. 31-60.

Coser, L.A. (1975). Społeczne funkcje konfliktu. W: W. Derczyńska, A. Jasińska-Kania, J. Szacki (red.), Elementy teorii socjologicznych. Materiaty do dziejów wspótczesnej socjologii zachodniej (s. 196-214). Warszawa: Państwowe Wydawnictwo Naukowe.

Dahrendorf, R. (2012). Klasy i konflikt klasowy w spoteczeństwie przemystowym. Kraków: Nomos.

Dmochowska-Dudek, K. (2011). Obiekty NIMBY jako przykład konfliktowych inwestycji na terenach mieszkaniowych - teoretyczny zarys problemu. Space - Society - Economy, 10, s. $29-56$.

Dudek-Mańkowska, S., Lackowska-Madurowicz, M. (2012). Konflikty społeczne na Mazowszu - identyfikacja oraz próba oceny ich wpływu na rozwój lokalny. Mazowsze. Studia Regionalne, 10, s. 125-144.

Dutkowski, M. (1995). Konflikty w gospodarowaniu dobrami środowiskowymi. Gdańsk: Wyd. UG.

Dutkowski, M. (1996). Konflikty środowiskowe w ujęciu wielodyscyplinarnym. W: R. Domański (red.), Nowa generacja w badaniach gospodarki przestrzennej. Biuletyn KPZK PAN, 174, s. $29-47$. 
Głogowska, M., Szendera, W., Chmielewski, W. (2013). Konflikty społeczne na obszarach natura $2000 \mathrm{w}$ Polsce. Woda - Środowisko - Obszary Wiejskie, 13, 4 (44), s. 31-41.

Grocholska, J. (1980). Obszary konfliktowe - problem badawczy w przestrzennym zagospodarowaniu kraju. Przeglad Geograficzny, 52, 3, s. 507-5017.

Grocholska, J. (1986). Konflikty w planowaniu przestrzennym i próby ich rozwiązania (na przykładzie wybranych obszarów aglomeracji warszawskiej). Studia nad funkcjonalnym makroregionem Warszawy (III). Biuletyn Informacyjny, 53, s. 205-222.

Jermakowicz, P. (2014). Konflikt społeczny - zagadnienia teoretyczne. W: M. Plucińska (red.), Rozwiazyywanie sytuacji konfliktowych w wymiarze jednostkowym i społecznym (s. 11-20). Poznań: Wyd. Wydziału Nauk Społecznych UAM.

Kiełczewska-Zaleska, M. (1972). Geografia osadnictwa, Warszawa: Państwowe Wydawnictwo Naukowe.

Kurek, S., Wójtowicz, M., Gałka, J. (2014). Wptyw suburbanizacji na przemiany wybranych struktur demograficznych i powiazan funkcjonalno-przestrzennych w Krakowskim Obszarze Metropolitalnym. Kraków: Wyd. UP.

Lisowski, A., Grochowski, M. (2008). Procesy suburbanizacji. Uwarunkowania, formy i konsekwencje. W: K. Saganowski, M. Zagrzejewska-Fidorowicz, P. Żuber (red.). Ekspertyzy do Koncepcji Zagospodarowania Przestrzennego Kraju. T. 1 (s. 217-280). Warszawa: Ministerstwo Rozwoju Regionalnego.

Majer, A. (2000). Konflikty miejskie Próba rozwinięcia tematu. W: M. Malikowski, Z. Seręga (red.), Konflikty społeczne w Polsce w okresie przemian systemowych. Studia. Komunikaty. Eseje, t. II (s. 81-92). Rzeszów: Wyd. WSP.

Mantey, D. (2016). Potencjalne konflikty przestrzenne w strefie podmiejskiej z perspektywy potrzeb mieszkańców na przykładzie podwarszawskiej gminy Lesznowola. Studia Regionalne i Lokalne, 3 (65), s. 117-138.

Markowski, T. (1999). Zarzadzanie rozwojem miast. Warszawa: Wyd. Naukowe PWN.

Moore, Ch.W. (1996). The mediation process. Practical strategies for resolving conflict. San Francisco: Jossey-Bass Publication.

Mucha, J. (2014). Socjoterapeutyczne aspekty zarządzania sytuacją konfliktową w wymiarze jednostkowym i społecznym. Kilka uwag wprowadzających. W: M. Plucińska (red.), Rozwiazywwanie sytuacji konfliktowych w wymiarze jednostkowym i społecznym (s. 23-36). Poznań: Wyd. Wydziału Nauk Społecznych UAM.
Pawlak, H. (2014). Konflikty społeczne i przestrzenne w strefie podmiejskiej. W: A. Zborowski (red.), Cztowiek - społeczeństwo - przestrzeń, t. 6 (s. 33-48). Myczkowce-Kraków: IGiGP UJ, Centrum Kultury Ekumenicznej.

Pawlak, H. (2017). Postawy mieszkańców wsi strefy podmiejskiej Krakowa wobec procesów suburbanizacji. Praca doktorska niepublikowana, Kraków: IGiGP UJ.

Przewoźniak, M. (2008). Konflikty w zagospodarowaniu przestrzennym bałtyckiego obszaru przybrzeżnego w Polsce. W: K. Furmańczyk (red.). Zintegrowane zarządzanie obszarami przybrzeżnymi w Polsce - stan obecny i perspektywy. Część 3: Morze - ląd. Wzajemne relacje (s. 29-43): Szczecin, SoftVision.

Runge, J. (2011). Społeczno-gospodarcze oraz przestrzenne przejawy suburbanizacji $\mathrm{w}$ województwie śląskim. W: J. Słodczyk (red.). Procesy suburbanizacji w wybranych miastach Polski. Studia Miejskie, 3, s. 55-65.

Sielezin, J.R. (2010). Teoretyczne problemy konfliktów społeczno-politycznych i ich specyfika. Próba egzemplifikacji. Wroctawskie Studia Politologiczne, 11, s. 64-77.

Simmel, G. (1975). Socjologia. Warszawa: Państwowe Wydawnictwo Naukowe.

Śleszyński, P., Solon J. (red.) (2010). Prace planistyczne a konflikty przestrzenne w gminach. Studia KPZK PAN, 130.

Turzyński, M. (2017). Zróżnicowanie depopulacji wynikającej z migracji na przykładzie Trójmiasta. Konwersatorium Wiedzy o Mieście, 2 (30), s. 67-73.

Zborowski, A. (2005). Przemiany struktury społeczno-przestrzennej regionu miejskiego w okresie realnego socjalizmu i transformacji ustrojowej (na przykładzie Krakowa). Kraków: IGiGP UJ.

Zborowski, A., Chaberko, T., Kretowicz, P. (2011). Procesy suburbanizacji rezydencjonalnej w regionie miejskim Krakowa - przemiany społeczno-przestrzenne. W: J. Jakóbczyk-Gryszkiewicz (red.), Regiony miejskie w Polsce 20 lat po transformacji. Łódź: Wyd. UŁ, s. 11-34

Zborowski, A., Gałka, J., Śliwińska, D. (2016). Procesy suburbanizacji i peryurbanizacji - zagadnienia teoretyczne. W: A. Zborowski (red.), Człowiek - spoteczeństwo - przestrzeń, t. 9 (s. 157177). Myczkowce-Kraków: IGiGP UJ, Centrum Kultury Ekumenicznej.

Zborowski, A., Raźniak, P. (2013). Suburbanizacja rezydencjonalna w Polsce - ocena procesu. Studia Miejskie, 9, s. 37-50.

Zborowski, A., Trafas, K. (2003). System osadniczy - hierarchia ośrodków. Krakowski Obszar Metropolitalny (KOM). W: Plan zagospodarowania województwa małopolskiego - projekt (s. 158165). Kraków: Departament Środowiska i Rozwoju Wsi, Instytut Geografii i Gospodarki Przestrzennej UJ, Urząd Marszałkowski Województwa Małopolskiego.

Artykuł wpłynął 11 października 2019 Zaakceptowano do druku: 5 grudnia 2019 